\title{
Pembesaran Lele Dalam Drum dan Pemanfaatan Limbah Lele Pada Tanaman Kangkung dan Tabulampot di Desa Tegalboto, Kecamatan Sumbersari, Kapubaten Jember
}

\author{
Atok Ainur Ridho $^{1 *}$, Insan Wijaya ${ }^{2}$, Bagus Tripama ${ }^{2}$ \\ ${ }^{1}$ Jurusan Agribisnis, Universitas Muhammadiyah Jember \\ ${ }^{2}$ Jurusan Agronomi, Universitas Muhammadiyah Jember
}

atok.aridho@unmuhjember.ac.id

\begin{abstract}
Branch of Muhammadiyah Tegalboto Kidul is a forum for Muhammadiyah da'wah activities within the scope of the village level. Muhammadiyah's space for movement is not only in religious activities, but in social, economic and other fields. The activity program of the Muhammadiyah branch of Tegal Boto Kidul which has been running so far is only in the routine study of recitation and social movements such as compensation for the needy. Activities related to economic development in branch members in particular and the surrounding community have generally not been carried out much. The purpose of this community service is to provide education to the community as a solution to limited land owned but still able to carry out fish farming and vegetable and fruit farming activities. This service aims to optimize the narrow land with a fish farming system in small media, does not require large areas, is cheap, is easily available media and technology that can be carried out by all groups of society at large. This service is expected to be a solution to the problem of limited land for fish cultivation, especially in cities, the problem of decreasing the availability of aquaculture and the problem of the need for fish animal protein in the community. The implementation of this community activity has been carried out during pandemic Covid-19 in Tegalboto Village, Sumbersari District, Jember Regency, including counseling, education and training on "budidakmber", measuring the quality of cultivated water, measuring the weight of catfish.
\end{abstract}

Keywords : catfish, budidakmber, narrow field, branch of Muhammadiyah

\begin{abstract}
Abstrak
Ranting Muhammadiyah tegalboto Kidul merupakan wadah kegiatan dakwah Muhammadiyah dalam ruang lingkup tingkat desa. Ruang gerak Muhammadiyah tidak hanya dalam kegiatan keagamaan semata, melainkan bergerak dalam bidang sosial, ekonomi dan lain sebagainya. Program kegiatan ranting Muhammadiyah tegal boto kidul yang berjalan selama ini hanya dalam kajian rutin pengajian dan gerakan sosial seperti halnya santunan masyarakat yang membutuhkan. Kegiatan yang terkait pengembangan ekonomi pada anggota ranting khususnya dan masyarakat sekitar umumnya belum banyak dilakukan. Tujuan dari pengabdian masyarakat ini adalah untuk memberikan pendidikan pada masyarakat sebagai solusi keterbatasan lahan yang dimiliki namun masih dapat melakukan kegiatan usaha budidaya ikan dan bertanam sayuran serta buah. Pengabdian ini bertujuan mengoptimalisasikan lahan sempit dengan sistem budidaya ikan dalam media kecil,tidak membutuhkan lahan luas, murah, mudah tersedia media dan teknologi yang dapat dilakukan oleh semua kalangan masyarakat secara luas. Pengabdian ini diharapkan mampu menjadi solusi dari permasalahan keterbatasan lahan budidaya ikan khususnya diperkotaan, permasalahan penurunan ketersediaan budidaya perikanan dan permasalahan kebutuhan protein hewani ikan di masyarakat. Pelaksanaan kegiatan masyarakat ini telah dilakukan saat masa pandemi Covid-19 di Desa Tegalboto Kecamatan Sumbersari Kabupaten Jember meliputi Penyuluhan, Pendidikan dan pelatihan budidakmber, Pengukuran kwalitas air budidaya, Pengukuran berat ikan lele.
\end{abstract}

Kata Kunci : lele, budidakmber, lahan sempit, ranting Muhammadiyah

*Penulis Korespondensi : Atok Ainur Ridho 


\section{PENDAHULUAN}

Bahan pangan yang mengandung protein tinggi dan mudah dicerna salah satunya adalah Ikan. Pola kandungan asam-asam aminonya hampir sama dengan asam amino yang terdapat dalam tubuh manusia. Ikan air tawar yang cukup populer pada masyarakat Indonesia adalah ikan lele. Ikan lele merupakan jenis ikan yang hidup di air tawar. Habitat ikan ini di sungai-sungai atau persawahan, namun pada jaman sekarang ini ikan lele sudah sangat banyak dibudidayakan oleh para peternak ikan. Keunggulan ikan air tawar jika dibandingkan dengan ikan air laut adalah didalam ikan air tawar kandungan metil merkuri sangat rendah bankan terkadang tidak di temukan. Sedangkan ikan air laut sangat sering dijumpai kandungan metil merkuri yang cukup tinggi. Berikut merupakan tabel hasil penelitian kandungan gizi ikan lele per100 gr.

Tabel 1. Kandungan Gizi dalam 100g Ikan Lele

\begin{tabular}{|l|c|}
\hline \multicolumn{1}{|c|}{ Jenis zat } & Kandungan zat \\
\hline Kadar air & $78,5 \%$ \\
\hline Sumber energi & $90 \mathrm{kal}$ \\
\hline Protein & $18,7 \mathrm{gr}$ \\
\hline Lemak & $1,1 \mathrm{gr}$ \\
\hline Kalsium & $15 \mathrm{mg}$ \\
\hline Fosfor & $126 \mathrm{mg}$ \\
\hline Zat Besi & $2 \mathrm{mg}$ \\
\hline Natrium & $15 \mathrm{mg}$ \\
\hline Thiamin (Vit B1) & $0,1 \mathrm{mg}$ \\
\hline Riboflavin (Vit B2) & $0,05 \mathrm{mg}$ \\
\hline Niacin & $2 \mathrm{mg}$ \\
\hline
\end{tabular}

Berdasarkan penelitian tersebut menunjukkan betapa banyaknya kandungan protein yang terdapat dalam ikan lele. Jumlah protein tersebut cukup untuk mencukupi kebutuhan protein harian manusia. Ikan lele juga mengandung Leusin yang merupakan asam amino esensial yang sangat diperlukan untuk pertumbuhan anak-anak dan menjaga keseimbangan nitrogen. Leusin juga berfungsi untuk perombakan dan pembentukan protein otot. Beberapa manfaat ikan lele untuk kesehatan antara lain:

\section{Sebagai Sumber Protein}

Didalam protein ikan lele terkandung asam amino esensial lisin, metionin dan leusin yang lebih tinggi jika dibandingkan yang terkandung didalam susu dan daging. Leusin berguna untuk memebantu proses pertumbuhan pada anak. Ikan air tawar ini apabila dikonsumsi dapat menjadi sumber protein hewani yang bisa mencukupi kebutuhan harian anda.

\section{Pembentukan Tulang dan gigi}

Didalam ikan lele kandungan fosfor cukup tinggi yang berguna untuk memberi energi dalam metabolisme. Fosfor juga berfungsi membantu penyerapan kalsium. Pada ibu hamil fosfor berguna untuk pembentukan tulang pada janin, apabila asupan fosfor untuk janin kurang makan akan mengambilnya dari sang ibu, ini dapat menyebabkan sang ibu mengalami osteoporosis. Fosfor merupakan mineral urutan kedua dalam daftar mineral yang sangat dibutuhkan tubuh. Mineral ini sangat berperan dalam pembentukan tulang dan gigi. Kekurangan mineral fosfor ini bisa sangat berbahaya bagi kesehatan tubuh anda, karena anda dapat menderita tulang keropos yang dapat berujung kelumpuhan apabila berlangsung sangat lama.

3. Baik untuk Otak dan Jantung

Walaupun harga ikan ini relatif murah, akan tetapi kandungannya tidak kalah jika dibanding dengan ikan salmon dan tuna. Ikan lele juga mengandung asam omega 3 dan omega 6 yang sangat baik bagi kinerja otak serta dapat mencegah penyakit jantung. Mengkonsumsi ikan lele secara rutin dapat menurunkan kolesterol, diabetes serta jantung kororner. Asam omega3 juga membantu perkembangan otak dan fungsi penglihatan pada bayi.

\section{Menurunkan Tekanan Darah}

Beberapa penelitian menemukan pula manfaat dari asam omega3 bagi tubuh yaitu dapat menurunkan tekanan darah tinggi, merawat kesehatan kulit terutama dari ekzema dan dermatitis, serta berperan dalam pembentukan cortese otak.

Berdasarkan aspek ekonominya, jenis ikan lele merupakan ikan yang cukup popular dikonsumsi di kotakota maupun dipedesaan. Sedangkan khususnya di daerah Jember ini, keberadaan ikan lele mudah kita ditemui, baik itu dalam bentuk ikan segar maupun dalam bentuk produk masakan. Kepala Seksi Budidaya Perikanan Dinas Peternakan, Perikanan, dan Kelautan Jember menyatakan bahwa produksi berbagai jenis ikan 
air tawar di Kabupaten Jember terus mengalami peningkatan seiring dengan meningkatnya permintaan konsumen yang mengonsumsi ikan air tawar tersebut.

Kelurahan Tegalgede merupakan salah satu kelurahan di Kecamatan Sumbersari Kabupaten Jember yang berjarak sekitar $\pm 1 \mathrm{~km}$ dari kampus UNMUH. Batas-Batas wilayah Kelurahan Tegalgede adalah: Sebelah Utara : Desa Antirogo Sebelah Selatan : Kelurahan Sumbersari Sebelah Tmur : Desa Karangrejo Sebelah Barat : Kelurahan Patrang Jumlah penduduknya pada tahun 2018 sebesar 9.581 orang yang terdiri dari penduduk laki-laki sebesar 4.738 orang dan penduduk wanita sebesar 4.843 orang. Total luas wilayah Kelurahan Tegalgede sebesar 188,4 Ha. Luas wilayah pemukiman sebesar $80,2 \mathrm{Ha} / \mathrm{m} 2$ atau $42,6 \%$ dari total wilayah, luas pekarangan $41 \mathrm{Ha} / \mathrm{m} 2$ atau $21,8 \%$ dari total wilayah dan persawahan sebasar $8,2 \mathrm{Ha} / \mathrm{m} 2$ atau 4,3\% dari total wilayah. Pada awalnya lahan pertanian berupa sawah dan tegalan yang dimiliki Kelurahan Tegalgede cukup luas. Namun, seiring dengan semakin bertambahnya jumlah penduduk di Kabupaten Jember menyebabkan lahan pertanian tersebut beralih fungsi menjadi pemukiman penduduk. Hal ini terlihat dari data kelurahan Tegalgede bahwa prosentase wilayah pemukiman sebesar 42,6\%. Pada akhirnya, produksi produk-produk pertanian di Kelurahan Tegalgede pun mengalami penurunan dari tahun ke tahun. Padahal kebutuhan pangan yang diperoleh dari produk-produk pertanian selalu mengalami peningkatan. Pada akhirnya mereka tidak dapat menanam tanaman untuk menghijaukan pekarangan rumahnya serta sumber pendapatannyapun ikut menurun. Salah satu penyebab sempitnya rumah dan pekarangan yang dimiliki mengakibatkan rendahnya pendapatan yang diperoleh keluarga. Lahan pekarangan yang sempit sebenarnya masih dapat dimanfaatkan untuk kegiatan budidaya. Salah satu teknik budidaya yang dapat diterapkan pada lahan yang sempit adalah biasa dikenal dengan sebutan Budidamber (Budidaya dalam Ember). Budidamber mengadaptasi teknik YuminaBumina yang merupakan teknik budidaya yang memadukan antara ikan dan sayuran serta buah-buahan.
Dalam pelaksanaan Pengabdian masyarakat yang akan kami terapkan adalah budidaya/pembesaran ikan lele dengan alat berupa drum yang diintegrasikan dengan tanaman kangkung serta air limbah lele dimanfaatkan sebagai suplai nutrisi unsur hara pada tanaman tabulampot (tanaman buah dalam pot). Teknologi ini lebih menguntungkan dibandingkan dengan teknik budidaya konvensional (Rokhmah dkk, 2014). Budidaya sistem ini hampir identik dengan sistem akuaponik yang pada prinsipnya menghemat penggunaan lahan dan meningkatkan efisiensi pemanfaatan hara dari sisa pakan dan metabolisme ikan. Sistem ini merupakan budidaya ikan yang ramah lingkungan (Setijaningsih dan Umar, 2015). Dimusim pandemi covid 19 teknik budidaya ini layak diterapkan untuk meminimalisir pergerakan orang dan mendapatkan kebutuhan pemenuhan gizi dengan mudah dan murah.

Teknik Budidamber ini tidak memerlukan lahan yang luas, bahkan dapat dilakukan pada rumah yang tidak memiliki halaman sekalipun. Pemanfaatan teknik Budidamber ini memungkinkan untuk berkebun dengan memanfaatkan tempat secara efisien. Secara estetika, tanaman tabulampot berguna sebagai penutup pemandangan yang tidak menyenangkan atau sebagai latar belakang yang menyuguhkan pemandangan yang indah. Tingkat kesulitan budidaya ikan lele dalam drum tergantung dari kemahiran dan pengalaman serta wawasan yang dimiliki oleh pelaku budidaya. Hal ini dikarenakan pembudidaya harus memahami seluk beluk dalam budidaya ikan lele terkait dengan ukuran benih tebar, kepadatan tebar, kwalitas air, kondisi cuaca, perilaku dan kebiasaan hidup ikan, serta tanaman yang akan diintegrasikannya.

Model budidaya ini mudah diikuti dan dipraktekan, bahkan bahan-bahan yang digunakan mudah ditemukan sehingga dapat diterapkan termasuk oleh ibu-ibu rumah tangga. Jenis-jenis tanaman yang dibudidayakan biasanya adalah tanaman yang memiliki nilai ekonomi tinggi, berumur pendek atau tanaman semusim khususnya sayuran seperti kangkung dan memiliki sistem perakaran yang tidak terlalu luas yang berfungsi penyerap amoniak kotoran ikan. Bahan-bahan yang 
digunakan dapat berupa drum bekas/baru, botol bekas plastik/gelas plastik, kawat, tang, timbangan, bibit lele, pakan, probiotik, dan timba.

\section{METODE}

Pelaksanaan kegiatan pengabdian masyarakat dilakukan di masyarakat ranting Muhammadiyah tegalboto desa tegalboto kecamatan sumbersari dengan beberapa metode pendekatan yaitu, penyuluhan atau sosialisasi tentang Budidamber, pelatihan pembuatan Budidamber serta pendampingan manajeman. Pendekatan tersebut diharapkan dapat meningkatkan kesadaran masyarakat khususnya masyarakat mitra kegiatan tentang cara budidaya Ikan Lele sekaligus kangkung yang efektif dan efisien dalam wadah ember/drum serta manfaat air limbah sebagai sumber nutrisi hara tanaman tabulampot.

Untuk mencapai target solusi-solusi yang diusulkan, kegiatan ini dibagi dalam 3 tahap yaitu penyuluhan dan pelatihan (workshop) disertai pendampingan. Detail tahapan kegiatan ini diuraikan sebagai berikut:

\section{1) Penyuluhan}

Kegiatan pertama yang dilakukan adalah penyuluhan tentang metode Budidamber kepada masyarakat mitra pengabdian. Kegiatan ini dilakukan dengan metode ceramah serta diskusi. Tujuan kegiatan ini adalah untuk memberikan pengetahuan tentang cara memelihara ikan dalam ember/drum termasuk cara pemberian pakan dan pergantian air serta cara menanam kangkung dan pemanfaatan limbah air budidaya sebagai unsur hara tabulampot. Target dari penyuluhan ini dibuat untuk menggugah rasa semangat peserta pelatihan dalam meningkatkan pemahaman dalam pembesaran ikan lele dalam drum dan pemanfaatan limbahnya.

2) Pelatihan Pembesaran Lele dalam drum

Pelatihan ini merupakan kelanjutan dari materi penyuluhan sebelumnya yaitu pengenalan drum sebagai media tempat pembesaran ikan beserta botol aqua bekas sebagai media penempatan tanaman kangkung beserta mekanisme dalam berbudidaya dalam pembesaran ikan lele dalam drum. Pelatihan dibimbing oleh tim pengusul dibantu oleh 2 orang mahasiswa. Tahapan dalam pelatihan pembesaran lele dalam drum dibagi menjadi 2 tahap yaitu:

a) Bahan-bahan yang digunakan adalah Bibit lele ukuran 12-13, Drum Plastik, Botol Plastik/Gelas Plastik, Kawat, Air, Selang, Timba, Timbangan, Tang, Pelet, Probiotik, Kangkung, Tabulampot/Bunga

b) Cara membuat :

- Siapkan drum telah disediakan lalu diisi dengan air boleh air sumur ataupun air PDAM (lebih baik air sumur)

- Diamkan air yang ada dalam drum minimal 24 jam atau 1 minggu untuk mensterilkan dan penumbuhan plankton

- Masukkan benih / bibit lele dengan ukuran 7-8 atau ukuran yang lain(Ukuran fleksibel) sesuai dengan bibit yang dikehendaki. Makin besar bibit semakin cepat dipanen.

- Siapkan botol aqua plastik yang telah dipotong 1/3 bagian bawah/ gelas aqua plastik yang telah dilubangi beberapa sudut gelas.

- Lubangi botol aqua plastik atau gelas aqua plastik bagian atas dan masukkan kawat pada lubang tersebut dan dibentuk kawat sesuai fungsi untuk dikaitkan pada pinggiran drum.

- Beli kangkung yang ada dipasaran lalu potong kangkung tersebut kurang lebih $15 / 20 \mathrm{~cm}$ pada bagian bawah untuk dijadikan bibit yang ditanam dan potongan kangkung bagian atas bisa kita masak.

- Masukkan bibit kangkung pada botol/gelas plastik bekas yang telah disiapkan.

- Rawat ikan lele dalam drum dengan pemberian jenis pakan dan prosentase pakan sesuai dengan usia ikan.

- Limbah air ikan bisa dimanfaatkan untuk tabulampot pada ikan usia 15 hari setelah tanam dan seterusnya tiap 3 hari sekali dapat dimanfaatkan.

- Kangkung dapat dipanen pertama kali pada usia 15-21 hari dari mulai tanam dan setelah itu bisa tiap minggu/10 hari sekali. 


\section{3) Pendampingan}

Setelah dilakukan pelatihan maka tim pengabdian melakukan pendampingan terhadap mitra dalam hal ini adalah perwakilan masyarakat ranting Muhammadiyah tegalboto kidul yang mendapatkan sarana peralatan dengan jumlah 10 orang sehingga dalam pendampingan tersebut mitra dapat menjalankan usaha dan mencapai apa yang diharapkan. Selain itu tim pengabdian juga melakukan persiapan prakondisi sosial yakni penguatan kelompok pelatihan dilanjutkan dengan melakukan pembinaan usaha ikan lele dalam drum serta pemantauan, evaluasi dan pelaporan.

\section{HASIL DAN PEMBAHASAN}

Pelaksanaan kegiatan ini dibagi menjadi 3 tahapan yaitu; (1) penyuluhan; dan (2) pelatihan pembesaran lele dalam drum (3) pendampingan. Detail masingmasing tahapan diuraikan sebagai berikut:

\section{Penyuluhan}

Penyuluhan meliputi tentang cara pembesaran lele terkait dengan pakan, kondisi air, jenis bibit lele, penyakit serta manfaat limbah limbah padat dan cair sebagai nutrisi tanaman sayuran (kangkung) dan tabulampot. Kegiatan ini diikuti 24 orang masyarakat ranting Muhammadiyah tegalboto kidul dan tim yang bertempat di musholla an nur, kecamatan sumbersari, kabupaten Jember. Peserta penyuluhan antusias menyimak kegiatan ini. Kegiatan ini ditutup dengan sesi tanya jawab.

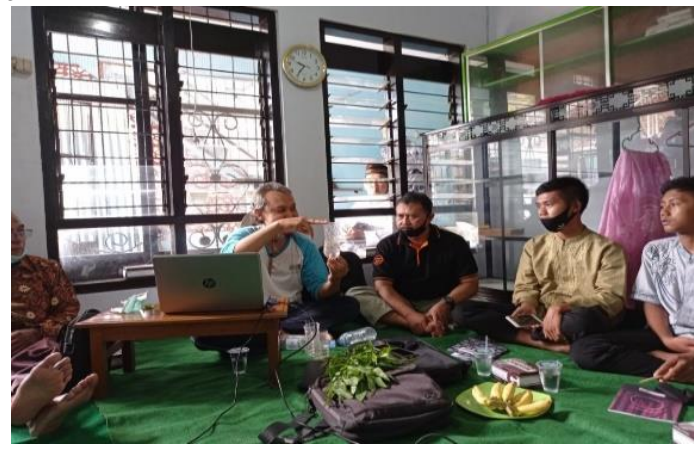

Gambar 1. Kegiatan Penyuluhan

2. Pelatihan Pembesaran Lele dalam drum

Pelatihan Pembesaran Lele dalam drum dilakukan setelah sesi penyuhan. Pelatihan pembesaran lele dalam drum dimulai dari proses persiapan drum dan diisi air, pembuatan media tempat sayuran kangkung yang terbuat dari botol plastik bekas, pemotongan sayuran kangkung serta tabur benih ikan lele.

a. Pengisian air dalam drum

Drum yang dilakukan sebagai tempat pembesaran ikan lele adalah drum yang berkapasitas 160 L. Hal ini dilakukan untuk menyesuaikan kepadatan ikan lele yang ditebar agar mendapatkan pertumbuhan yang optimal. Drum diisi air dan air diendapkan minimal 24 jam atau lebih yang bertujuan menetralkan air serta menumbuhkan planton sebagai media pakan alami ikan, semakin lama diendapkan semakin baik. Biasanya para peternak ikan menamainya air jadi dengan parameter air berwarna kehijauan.

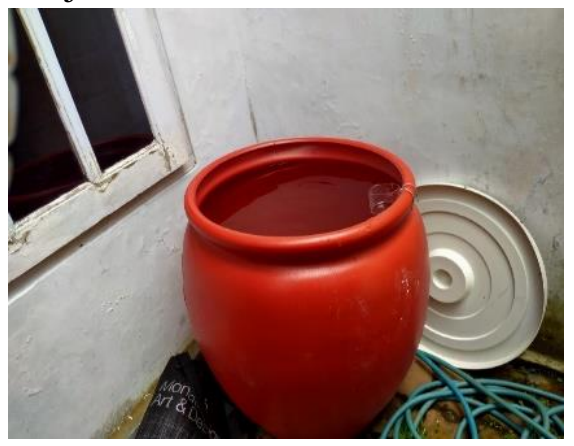

Gambar 2. Pengisian Air dalam Drum

b. Pembuatan media tempat sayuran

Pembuatan media tempat sayuran kangkung dibuat dari botol plastik bekas yang dipotong $1 / 3$ bagian dan bagian $2 / 3$ dari potongan dijadikan sebagai tempat media tanam sayuran dengan bagian atas diberi dua lubang yang di masuki kawat yang sudah dipotong kurang lebih $20 \mathrm{~cm}$ sebagai pengait pada bibir drum.

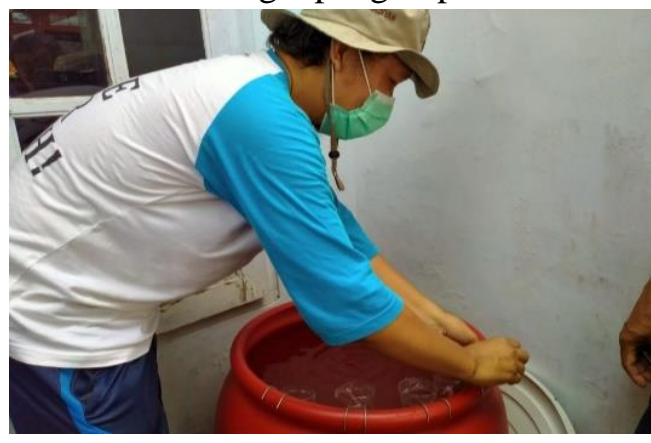

Gambar 3. Pembuatan Media Tempat Sayuran 
c. Pemotongan sayuran

Pemotongan sayuran dalam hal ini kangkung kurang lebih sejengkal batang bawah yang akan dijadikan bibit pertumbuhan sayur. Kangkung yang ditanam pada media air botol bekas bisa dipanen setelah 3-4 minggu setelah tanam.

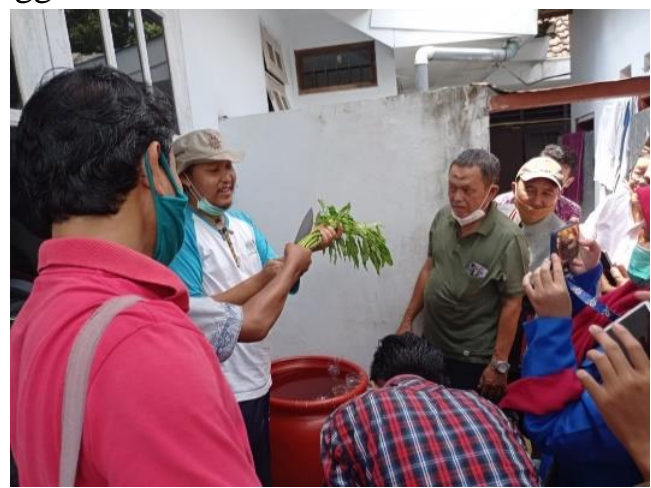

Gambar 4. Pemotongan Sayuran

d. Penebaran bibit lele.

Pada proses penebaran bibit ikan lele hendaknya bibit ikan lele tidak langsung ditebar, akan tetapi diletakkan pada tempat/ media tebar (drum) terlebih dahulu untuk menyesuaikan suhu antara air yang ada dalam drum dan air pada kantong plastik ikan lele. Hal ini dilakukan untuk menghindari kematian yang diakibatkan kondisi temperatur suhu air yang berbeda yang mengakibatkan ikan lele mengalami stres.

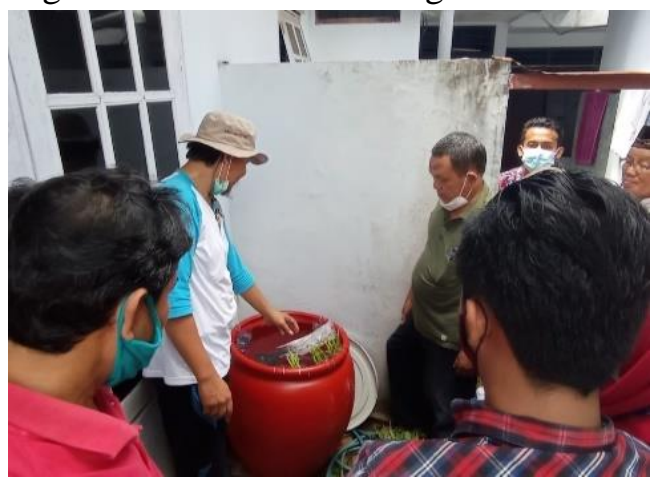

Gambar 5. Penebaran Bibit Lele

\section{Pendampingan}

Pendampingan dilakukan kepada 10 anggota masyarakat yang mendapatkan bantuan peralatan agar dalam pelaksanaan aktifitas kegiatan sesuai apa yang telah diberikan pada saat penyuluhan dan pelatihan serta memberikan masukan sebagai solusi ketika terjadi permasalahan atau kendala yang dihadapi pelaku kegiatan pembesaran lele dalam drum.

\section{KESIMPULAN}

Dari hasil dan pembahasan dapat disimpulkan bahwa :

1. Masyarakat Ranting Muhammadiyah Tegalboto kidul Kecamatan sumbersari Kabupaten Jember sangat antusias menyambut program Pengabdian Masyarakat yang diadakan tim Fakultas Pertanian Universitas Muhammadiyah Jember dan menyampaikan rasa terimakasih yang besar atas program pengabdian masyarakat tersebut

2. Hasil yang diperoleh secara signifikan adalah adanya tambahan pengetahuan dari tim pelaksana kepada masyarakat pembudidaya pembesaran lele dalam drum

3. Terciptanya kerjasama yang baik antara dunia kampus dengan masyarakat serta memantapkan kemampuan mahasiswa dalam melakukan komunikasi, penyuluhan, dan penyebaran ilmu kepada masyarakat.

\section{UCAPAN TERIMA KASIH}

Ucapan terimakasih disampaikan kepada LPPM Universitas Muhammadiyah Jember yang telah membiayai kegiatan pengabdian ini melalui Program Pengabdian Sumber Dana Internal 2021

\section{DAFTAR PUSTAKA}

Budidaya Ikan Air Tawar di Jember Tinggi Minat Rendah, Bangsa Online - Cepat, Lugas dan Akurat.htm

Budidaya Ikan Dalam Ember "Budikdamber" dengan Aquaponik di Lahan Sempit, Prosiding Seminar Nasional Pengembangan Teknologi Pertanian Politeknik Negeri Lampung 08 Oktober 2018

H Rukmana H. dan Yudirachman H Sukses Bididaya Lele secara Intensif, PT lily Publisher 2017

Kecamatan Sumbersari Dalam Angka, Badan Pusat Statistik Kabupaten Jember, 2018

Kandungan Gizi Ikan Lele dan Manfaatnya Bagi Kesehatan Bibit ikan.net.htm 
PT Lily Publisher 2009 Meraup Untung dari beternak lele sangkuruang, Yogyakarta

Panjaitan. H. 2014 Budidaya Pembesaran Lele Dumbo Instruktur Penyelia BPPP-Medan

Rokhmah, N. A., C. S. Ammatillah dan Y. Sastro. (2014). Mini Akuaponik untuk Lahan Sempit di Perkotaan. Buletin Pertanian Perkotaan Volume 4 Nomor 2, 2014 | 14. Balai Pengkajian Teknologi

Setijaningsih, L dan C. Umar. 2015. Pengaruh Lama Retensi Air Terhadap Pertumbuhan Ikan Nila (Oreochromis Niloticus) Pada Budidaya Sistem Akuaponik dengan Tanaman Kangkung. Berita Biologi, Jurnal Ilmu-ilmu Hayati. ISSN 0126-1754 636/AU3/P2MI-LIPI/07/2015 Volume 14 Nomor 35.

Tim Redaksi Agromedia Pustaka, Anda bertanya, Pakar dan Praktisi Menjawab 